\title{
Motivation for Change in Substances Use among Drug Users Referred by the Justice System
}

\author{
Itamar José Félix Junior ${ }^{*}, 1$ \\ Orcid.org/0000-0001-6350-5194 \\ Paulo Renato Vitória Calheiros ${ }^{1}$ \\ Orcid.org/0000-0003-1897-4180 \\ Pedro di Tárique Barreto Crispim ${ }^{1}$ \\ Orcid.org/0000-0003-1243-348X
}

${ }^{1}$ Universidade Federal de Rondônia, Porto Velho, RO, Brasil

\begin{abstract}
The Therapeutic Justice project, which refers people with psychoactive substance dependence who committed crimes for treatment, has gained prominence in Brazil. This study aimed to evaluate the stages of motivation in people referred by the justice system for the treatment of psychotropic substance dependence. The sample consisted of 120 people who were being treated in CAPS-AD and Therapeutic Communities in the city of Porto Velho, Rondônia, Brazil. The individuals were divided into two groups, one formed by people referred by the justice system (Justice System Group) and another made up of people who were being treated for any other reason (Others Group), to compare the motivation to change behavior between the groups. The URICA Scale for Illicit Substances, the Readiness Ruler and Readiness for Change were used to evaluate the motivation variables of the groups. The results showed that there were no statistically significant differences in motivation between the people referred by the justice system and the people with other more usual forms of indication for treatment. The importance of assessing the motivation during all stages of treatment is emphasized, aiming for better adherence and therapeutic success of people with problems with the law and the use of substances.
\end{abstract}

Keywords: Therapeutic Justice, motivation to change behavior, drug addiction, treatment.

\section{Motivação para Mudança no Uso de Substâncias entre Usuários de Drogas Encaminhados pela Justiça}

\section{Resumo}

O projeto Justiça Terapêutica, que encaminha para tratamento pessoas com dependência de substâncias psicoativas que cometeram crimes, tem ganhado destaque no Brasil. Este estudo teve como objetivo avaliar os estágios de motivação em pessoas encaminhadas pela justiça para tratamento de dependência de

* Mailing address: Av. Jatuarana, 5695, Bairro Floresta, Porto Velho, RO, Brasil 76806-001. Phone: 69 999604489. E-mail: itamar.junior44@hotmail.com

Author's Note: Study developed in project of academic master of Psychology, without fomentation.

Support: CAPES, Comunidades Terapêuticas, Centro de Atenção Psicossocial-Álcool e Drogas (CAPS-AD),

Mestrado Acadêmico em Psicologia da Fundação Universidade Federal de Rondônia (MAPSI-UNIR). 
substâncias psicotrópicas. A amostra foi constituída por 120 pessoas que estavam em tratamento CAPSAD e internados em Comunidades Terapêuticas, na cidade de Porto Velho, Rondônia. Os indivíduos foram alocados em dois grupos para comparação da motivação para mudança de comportamento: um formado por pessoas encaminhadas pela justiça (Grupo Justiça) e o outro constituído por pessoas que estavam em tratamento por qualquer outro motivo, exceto encaminhamento judicial (Grupo Outros). Foram utilizados para avaliar as variáveis de motivação dos grupos a Escala URICA para substâncias Ilícitas, Régua de Prontidão e Prontidão para Mudança. Os resultados demonstraram que não foram encontradas diferenças estatisticamente significativas na motivação das pessoas encaminhadas pela justiça e as pessoas encaminhadas pelas formas de indicação mais usuais para tratamento. Ressalta-se a importância de avaliar a motivação em todas as fases do tratamento, em vista da melhor adesão e sucesso terapêutico das pessoas com problemas com a justiça e com o uso de substâncias.

Palavras-chave: Justiça Terapêutica, motivação para mudança de comportamento, tratamento dependência de drogas.

\section{Motivación para el Cambio de la Conducta Adictiva entre Consumidores de Drogas Enviadas por la Justicia}

\section{Resumen}

El proyecto Justicia Terapéutica hacia delante para tratar a personas con dependencia de sustancias psicoactivas que cometieron crímenes ha ganado importancia en Brasil. Este estudio tuvo como objetivo evaluar las etapas de la motivación en las personas enviadas por la justicia para el tratamiento de la dependencia de sustâncias psicotrópicas. La muestra fue de 120 personas que estaban siendo tratados en el CAPS-AD y em Comunidades Terapéuticas en la ciudad de Porto Velho, Rondonia. Los individuos fueron divididos en dos grupos, uno formado por personas enviadas por la justicia (Grupo de Justicia) y otro formado por personas que estaban siendo tratados por cualquier otra razón, excepto la remisión judicial (otro grupo), para comparar entre los grupos motivación para cambiar comportamiento. Se utilizó para evaluar las variables de motivación de los grupos URICA Escala ilícito Regla de Preparación y disposición para el cambio. Los resultados mostraron que hubo diferencias estadísticamente significativas en la motivación de las personas enviadas por la justicia y las personas enviadas por las formas de indicación es más tratamientos habituales. Hacemos hincapié en la importancia de evaluar la motivación en todas las etapas del tratamiento, con el fin de una mejor adherencia y el éxito terapéutico de las personas con problemas con la ley y el uso de sustancias.

Palabras clave: Justicia Terapéutica, motivación para el cambio de comportamiento, tratamientos para la drogadicción.

Brazil faces a serious prison crisis, in which the number of inmates increases every year, without a corresponding increase in the number of places in prisons. Currently the country has the fourth largest prison population, with more than 600 thousand prisoners. Of these, $41 \%$ are provisional prisoners and $27 \%$ were arrested for drug trafficking (Ministério da Justiça, 2015). The vast majority of this population needs healthcare, motivated by many disorders, such as STDs and drug dependency. According to
Soares and Bueno (2016), the healthcare of inmates is deficient and is just one of the problems of the prison system. Overcrowding is, however, considered to be the biggest problem and prison conditions are unhealthy and dangerous to human health.

Some measures have been taken to reduce overcrowding. Among the alternatives are custodial hearings and the use of technology, such as electronic anklets (Soares \& Bueno, 2016). One project aimed at reducing overcrowding was 
also aimed at treating drug use and reducing the recurrence of crime. The project called "Therapeutic Justice" came about through the initiative of Rio Grande do Sul prosecutors motivated by the growing problem that involved drug users and the commission of crimes.

In addition to this, Law No. 11,343 was enacted in 2006, establishing the National System of Public Policies on Drugs (SISNAD), which included, for the first time, some articles that address the treatment for individuals with problems associated with drug use who have had legal problems. With this, there was the possibility for people involved with crimes and problems with drugs to be referred for treatment. Generally people who have committed crimes and are drug users have problems with more than one drug and have vulnerabilities that make it difficult to access and complete treatment. In this way, the motivation to achieve therapeutic success is determined as fundamental, especially with regard to obligatory treatments. Studies with adults have shown that motivation is an important factor in seeking, adherence and the positive outcome of therapeutic interventions for drug users (Prochaska, DiClemente, \& Norcross, 1992). Motivation, therefore, is one of the primary components for the treatment of drug addiction.

Motivational approaches are seen as fundamental in the treatment of drug users, especially regarding the adherence. Among the approaches, the Transtheoric Model (TTM) of Motivation for Change stands out, which initiated studies about the change in behaviors seen as problematic and that are often characterized by the difficulty in treatment or in adherence (Prochaska, 2013). The premise is that the change takes place in a process divided into different stages until it reaches effective change, with there being five stages, with flexibility between them. These stages are: Pre-contemplation, Contemplation, Preparation, Action and Maintenance. Pre-contemplation is characterized as a stage in which the person does not see that there are problems and does not consider change. In this stage, a person is not usually convinced that his or her behavior pattern is causing disorders and is thus unwilling to consider change (Oliveira, Ludwig, Freire, \& Zanetello, 2012). The Contemplation Stage is where the feeling of ambivalence between wanting to change or maintain behavior is configured. The person begins to think about the possibility of modifying his/her behavior. Preparation is the next stage following Contemplation, in which the individual may have found motives for change and begins to plan for change, establishing a "commitment" to the treatment. Action is the stage which is characterized by putting the chosen strategies into practice. In the Maintenance stage, the individual works and consolidates the gains obtained in the Action stage and prevents the relapse.

Motivated by the impact of motivation on the treatment, Polaschek, Anstiss, and Wilson (2010) compared algorithms of a scale called the Criminogenic Needs Inventory and of the URICA scale, aiming to validate the psychometric properties of the scale with 260 prisoners, in the evaluation of motivation for change in criminal behavior. The results indicated preliminary support for the reliability and validity of the URICA in assessing the stage of change related to criminal behavior with male prisoners. The study by El-Bassel et al. (1998) aimed to evaluate the psychometric quality of the URICA Scale and the motivation stage in a population of incarcerated women. The sample was divided into five groups: negation; not involved; ambivalent; decision-making and participation. The results showed that the "negation" group had scores above the mean in the Pre-contemplation subscale, while the "ambivalence" group scored above the mean in all the subscales.

In Brazil, Oliveira, Szupszynski, and DiClemente (2010) carried out a study in which they assessed the motivational stage and related it to treatment adherence in 103 adolescent offenders who used illicit substances and were complying with socio-educational measures. The results indicated that $66 \%$ of the adolescents did not adhere to the treatment and $69.3 \%$ were in the Pre-contemplation stage at the time of the initial evaluation. It was also possible to relate the presence of a Behavior Disorder to adherence, where a significant relationship was obtained, showing 
that those who had a disorder were less likely to adhere to the treatment.

Regarding interventions involving people with involvement in the legal system, a survey conducted by the National Institute on Drug Abuse (NIDA) of the USA concluded that the compulsory treatment model is as effective as the voluntary model. The study also found that compulsorily referred individuals were less motivated only at the beginning of treatment, however, over time they began to reflect on themselves and to recognize the need for treatment (Kelly, Finney, \& Moos, 2005). An analysis that reviewed the results of 50 studies that included experimental and quasi-experimental models for prisoners with drug problems indicated that they were less likely to relapse compared to prisoners who did not undergo any drug intervention (Wilson, Mitchell, \& MacKenzie, 2006).

A more recent motivation assessment study showed that parental support in drug treatment predicts greater motivation in adolescents, leading them to give more importance to the treatment (Serafini, Stewart, Wendt, \& Donovan, 2017). Thus, the change among people referred by the justice system and also among adolescent drug users is a challenge for therapists and institutions, in which the support network is an important adjuvant to the treatment.

In addition, the damage caused by the use of drugs ends up increasing the social vulnerability of the individual or of a group, and the opposite may occur: social vulnerability leading to increased drug consumption. Therefore, these aspects may determine greater risks for these individuals if they engage in attitudes that are in conflict with the law. All of these factors may be interlinked, and therefore, this relationship between crime and drug use needs to be studied in more depth in Brazil, especially in relation to the provision of treatment for drug users and motivation within the criminal justice system.

With these scenarios, the present study started from the hypothesis that the motivation of people referred by the criminal justice system would be different from that of people referred for treatment through other pathways, due to the belief that the referred subject would use the treatment as a reason not to be imprisoned and, therefore, would not take the treatment seriously, or would not be so motivated. Considering that the judicial referral of patients to treatment for drug dependence and use has been a practice that has gained prominence in Brazil generating the need to obtain information on this topic, this study aimed to assess the stage of motivation for change in patients referred by the criminal justice system for treatment for drug dependence in the Therapeutic Communities and in the Center for Psychosocial Care, Alcohol and other Drugs (CAPS-AD) of Porto Velho/RO.

\section{Method}

This was a cross-sectional, descriptive study comparing two groups (Justice System and Others), using quantitative methodology.

\section{Sample}

In total, the sample consisted of 120 participants. The selection of the sample was by convenience and the choice of institutions was made according to the location in which the participants referred by the criminal justice system were being treated. The Court of Execution of Prison Sentences and Alternative Measures (VEPEMA) provided a list of all registered institutions and the names of the people referred. The inclusion criterion was to be over 18 years of age, not to have used drugs in the previous 24 hours, to agree to participate in the study and not to have given up treatment, in the case of referrals. A referred person who disobeys or does not adhere to the treatment, giving up, risks being returned to prison or made to perform other alternative measures, such as Community Service. The exclusion criteria for the two groups were: less than 24 points in the Mini-Mental State Examination (MMSE) and presenting psychotic symptoms or syndromes.

The study participants were found in two treatment models offered in the state of Rondônia: hospitalization in institutions that called themselves Therapeutic Communities (TCs), corresponding to $74.2 \%(n=89)$, and in an outpatient model performed in the CAPS-AD, cor- 
responding to $25.8 \%(n=31)$. For comparative analysis, the participants were divided into two groups: "Justice System Group", formed by people referred for treatment by the criminal justice system and the "Others Group", made up of people who were being treated for various reasons other than judicial referral. There were five people $(4.16 \%)$ that refused to participate, three of them from the Justice System Group.

\section{Study Location}

The study was carried out in Therapeutic Communities and in the CAPS-AD of the city of Porto Velho. In all, nine institutions were visited. The majority of the TCs were philanthropic and maintained by donations, with the exception of three that had beds funded by the National Secretariat for Drugs Policy (SENAD) and the State Government.

\section{Instruments}

Mini-Mental State Examination (MMSE): this test is widely used in clinical environments for the screening of dementia. The MEEM was translated into Portuguese by Bertolucci, Brucki, Campacci, and Juliano (1994).

URICA for Illicit Substances (Rhode Island Change Assessment Questionnaire): The URICA for illicit substances (reduced version) was validated by Szupszynski and Oliveira (2008) from a study with users of illicit psychotropic substances. The internal consistency analysis of the validation was satisfactory $(\alpha=0.657)$. The instrument has 24 items subdivided into four subscales: Pre-contemplation (6 items); Contemplation (6 items); Action (6 items) and Maintenance (6 items).

Readiness Ruler: This consists of a ruler numbered from 0 to 10 with which the researcher will ask the patient which point on the ruler best reflects how ready he/she is at present to change the behavior (Velasquez, Maurer, Crouch, \& DiClemente, 2001).

Structured Interview: This was composed of open and closed items that addressed the following variables: (a) sociodemographic characteristics (age, gender, marital status, educational level, profession and occupation); (b) eligibility characteristics (inclusion and exclusion criteria); (c) pattern of drug use and associated problems; (d) previous treatments, previous life, use of medications; and (e) socioeconomic class, evaluated by the Brazilian Economic Evaluation Criterion 2015 (Associação Brasileira de Empresas de Pesquisa [ABEP], 2015).

\section{Data Collection Procedures}

The data collection procedures followed the specificities of the judicial referral for treatment, in which the Court of Execution of Prison Sentences and Alternative Measures (VEPEMA), through a team of professionals composed of psychologists and social workers responsible for the implementation of the pilot project "Therapeutic Justice" of the Criminal Justice Tribunal of Rondônia (TJRO), refers individuals for chemical dependency treatment in the place of their preference, after the analysis and decision of the judge. The referral can also occur before the end of the procedural analysis, when the subject requests the referral through legal action. Although the referral is not coercive or involuntary, the individual who does not adhere to treatment or leaves it can have this right withdrawn and thus, return to serve the sentence in a closed prison regime. The attempt was made to interview all the subjects who were referred.

The data collection was performed by research assistants, psychology students who were not aware of the study objectives and were previously trained in the application of the research instruments. The procedures for choosing the participants were as follows: in the TCs, participants who were not referred by the justice system (Others Group) were chosen through a draw from a list of all the inmates of the place, it which the people that composed the even numbers on the list were chosen. Data collection in the CAPS-AD was performed every Wednesday (days of group therapy) and on some days with medical consultations, as these were the days with more patients attending the institution. On these days, the individuals invited to participate in the study were those that comprised the even 
numbers on the waiting list to attend the groups or medical consultations.

\section{Ethical Procedures}

The study was approved by the Research Ethics Committee of the Federal University of Rondônia, under authorization No. 1.205.918 (CAAE: 44845215.1.0000.5300). All those who agreed to participate signed the consent form, according to Resolution No. 466/12 of the National Health Council. All of them responded individually to the study in appropriate places, in the institution itself, in sessions with an average duration of 25 minutes, during the period from October 2015 to March 2016.

\section{Data Analysis}

The information collected was processed in a spreadsheet in the Statistical Package for the Social Sciences (SPSS), version 20.0. The quantitative and ordinal variables were described by the minimum values $(\mathrm{Min})$, first quartile $\left(Q_{1}\right)$, median $(M e d)$, third quartile $\left(Q_{3}\right)$, maximum values (Max), mean $(X)$ and standard deviation $(S D)$. The nominal variables were described through their absolute frequencies and percent- ages. The Kolmogorov-Smirnov test was applied to test the normality of the distributions, and the non-parametric Mann-Whitney test for the verification of the comparison of the groups. The comparison between the proportions of the nominal variables was verified through the chisquared test. The level of significance was $5 \%$.

\section{Results}

The mean age $( \pm S D)$ of the sample was 35.21 years ( \pm 11.06 years). Descriptions of the sociodemographic characteristics are presented in Table 1. The two groups of subjects undergoing treatment were compared to assess the stage of motivation: the "Others Group" composed $70.8 \%(n=85)$ of the sample and the "Justice System Group" 29.2\% $(n=35)$.

Regarding the forms of referral for treatment of the participants of the Others Group: $40.9 \%(n=38)$ reported that they were undergoing treatment "voluntarily" without any indication; $30 \%(n=8)$ had been referred by the family, $12.9 \%(n=12)$ had help from friends, $8.6 \%(n=8)$ had assistance from community institutions or services, such as churches or shelters, and 3.3\% $(n=3)$ had been referred by health or welfare institutions.

Table 1

Description of the Sociodemographic Data of the Sample

\begin{tabular}{|c|c|c|c|c|}
\hline Variable & $\mathrm{n}$ & $\%$ & $\chi^{2}$ & $P$-value \\
\hline \multicolumn{5}{|l|}{ Sex } \\
\hline Male & 103 & $85,8 \%$ & \multirow{2}{*}{60.208} & \multirow{2}{*}{$<.0001$} \\
\hline Female & 17 & $14,2 \%$ & & \\
\hline \multicolumn{5}{|l|}{ Skin color } \\
\hline Brown & 74 & $61,7 \%$ & \multirow{3}{*}{51.800} & \multirow{3}{*}{$<.0001$} \\
\hline White & 36 & $30 \%$ & & \\
\hline Black & 10 & $8,3 \%$ & & \\
\hline \multicolumn{5}{|l|}{ Marital status } \\
\hline Single & 80 & $66,7 \%$ & \multirow{4}{*}{126.067} & \multirow{4}{*}{$<.0001$} \\
\hline Married/live with partner & 30 & $25 \%$ & & \\
\hline Separated/divorced & 09 & $7,5 \%$ & & \\
\hline Widowed & 01 & $0,8 \%$ & & \\
\hline
\end{tabular}


Has children

No

Yes

Education level

Incomplete elementary education

Complete high school

Incomplete high school

Social class
A

\section{B}
C

07

$0,8 \%$

Current employment situation

Unemployed
Employed
Informal work/self-employed
Retired

$\begin{array}{cc}74 & 61,7 \% \\ 27 & 22,5 \% \\ 18 & 15 \% \\ 01 & 0,8 \%\end{array}$

Committed crimes to buy drugs

$$
\text { Yes }
$$

$56,7 \%$

No

No

Spent the night on the streets in the previous six months

\begin{tabular}{cllll} 
Yes & 33 & $27,5 \%$ & 23.408 & $<.0001$ \\
No & 87 & $72,5 \%$ & & \\
\hline
\end{tabular}

Another highlighted point was the problems with drug use and crimes: in the total sample $56.7 \%$ reported having committed crimes to obtain drugs. Of the crimes committed by the participants of the Justice System Group $(n=35)$, $42.9 \%(n=15)$ had legal problems due to drug trafficking, $25.7 \%(n=9)$ due to theft, $11.4 \%$ $(n=4)$ were responding to the crime of domestic violence, $5.7 \%(n=2)$ for dangerous driving and $2.9 \%(n=1)$ per aggression.

Regarding the use of drugs that led the participants to seek treatment: the majority used crack 
(50.0\%); followed by cocaine $(22.5 \%)$, alcohol $(20.0 \%)$ and marijuana $(7.5 \%)\left(\chi^{2}=46,200, d f=3\right.$, $p<.0001)$. The median number of days undergoing treatment was $102.50\left(\mathrm{Min}=1.0, Q_{1}=53.75\right.$, $Q_{3}=180.00$, Max $=3650, X=142.56, S D=411.06$ ). The median number of days in abstinence was 90 (Min=1.0, $Q_{1}=30.50$, Med $=90.00, Q_{3}=180.00$, Max $=1825.0, \chi=142.56 ; S D=220.28)$. Comparing the groups, the median time in treatment of the Others Group was 96 days and that of the Justice System Group was 75 days. The median time of abstinence from the use of drugs of the Others Group was 90 days and that of the Justice Group was 75 days. It is also important to highlight the median time in abstinence comparing the treatment models, which was 97 days for the subjects that were being treated in TCs (Min $=0$ days, $Q_{1}=60.00, Q_{3}=180.00, \quad$ Max $=18$ days, $X=139.66, S D=207.63)$, and 30 days for those in the outpatient model (CAPS-AD; Min $=0$ days,
$Q_{1}=1.00, Q_{3}=210.00 ;$ Max $=910$ days, $X=150.90$, $S D=256.76$ ).

Of the total number of participants, $23.3 \%$ $(n=28)$ did not consider seeking treatment for themselves, of whom $35.7 \%(n=10)$ were from the Justice System Group. The median time in which the subject started considering treatment was 30.00 days, with no statistically significant difference between the Justice System $\left(\right.$ Med $=9.00$ days, $M i n=0$ days, $Q_{1}=0.00$, $Q_{3}=97.50$, Max $=440$ days, $X=72.47, S D=120.36$ ) and Others (Med $=30.00$ days, Min $=0$ days, $Q_{1}=1.00, Q_{3}=90.00$, Max $=5000$ days, $X=171.46$, $S D=575.23$ ) groups, with no statistically significant differences in the comparison (Mann-Whitney $U=1120.50, p=.111$ ).

Regarding the motivation variables, the data of the total sample of the Readiness Ruler, URICA Scale for Illicit Substances and Readiness for Change are described in Table 2.

Table 2

Description of the Readiness Ruler, URICA Scale and Readiness for Change

\begin{tabular}{ccccccccc}
\hline Variable & $N$ & Min & $Q_{1}$ & Med & $Q_{3}$ & Max & $\chi$ & $S D$ \\
\hline Readiness Ruler & $118^{*}$ & 0.00 & 5.00 & 8.00 & 9.00 & 10.00 & 7.07 & 2.74 \\
Pre-contemplation & 120 & 6.00 & 13.00 & 15.00 & 18.00 & 26.00 & 15.30 & 3.72 \\
Contemplation & 120 & 16.00 & 13.00 & 24.00 & 25.00 & 30.00 & 23.54 & 2.45 \\
Action & 120 & 14.00 & 24.00 & 26.00 & 28.00 & 30.00 & 25.72 & 3.03 \\
Maintenance & 120 & 14.00 & 21.25 & 23.00 & 25.00 & 30.00 & 23.13 & 3.33 \\
Readiness for change & 120 & 36.00 & 52.00 & 55.00 & 63.00 & 76.00 & 57.08 & 8.06 \\
\hline
\end{tabular}

Note. Min: minimum; Med: median; Max: maximum; $X$ : mean; SD: standard deviation.

* Two people did not know and/or did not want to respond, one being from the Others Group and one from the Justice System Group.

Regarding the internal consistency of the URICA Scale for Illicit Substances, the reliability based on Cronbach's coefficient was $\alpha=0.684$, presenting a level corresponding to the validation of the instrument (Szupszynski \& Oliveira, 2008). The level of Readiness for change was obtained from the sum of the scores of Contemplation, Action and Maintenance, subtracting the Pre-contemplation score, being, therefore, expressed as follows: Contemplation $(\mathrm{C})+\mathrm{Ac}-$ tion (A) + Maintenance (M) - Pre-contemplation $(\mathrm{PC})=$ total readiness $(\mathrm{TR})$. The data of the comparison between the Others Group and the Justice System Group, with minimum, median, maximum, mean and standard deviation values for the URICA subscales for Illicit Substances, Readiness Ruler and Readiness for Change are shown in Table 3.

The comparative data between the Justice System Group and the Others Group in relation to the Outpatient Treatment Model (CAPS-AD) and the Hospitalization Model (TCs), for the Readiness Ruler, the subscales of the URICA Scale and Readiness for Change are presented in Table 4. 


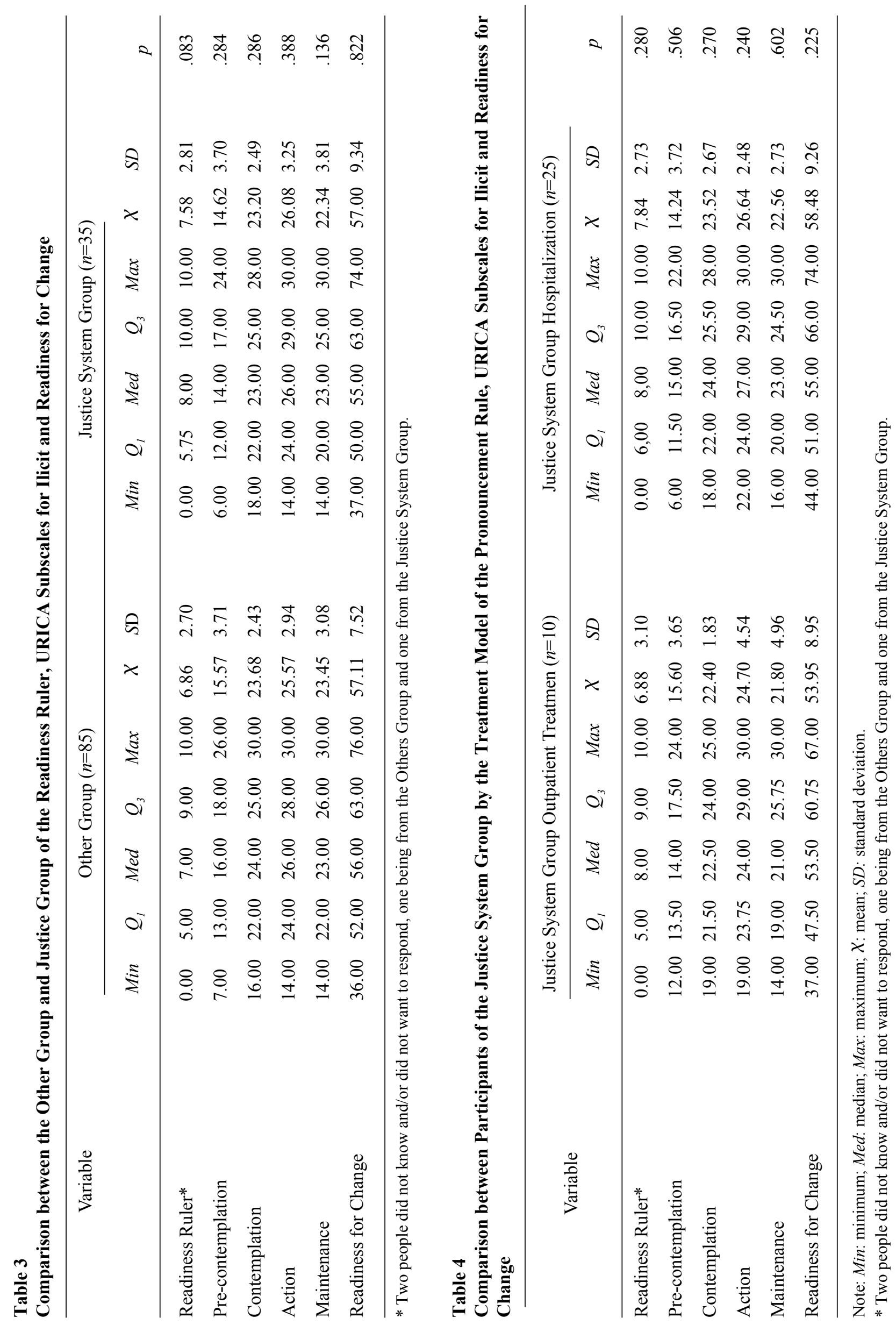


Questions were directed to the participants of the Justice System Group ( $n=35)$, in which $88.6 \%(n=31)$ were in prison prior to receiving the alternative chemical dependence treatment measure; $45.7 \%(n=16)$ were in treatment for crack use; $28.6 \%(n=10)$ for cocaine use; $14.3 \%$ $(n=5)$ for marijuana and $11.4 \%(n=4)$ for alcohol. Regarding the number of times the person had sought treatment prior to the referral: $34.3 \%$ $(n=12)$ were being treated for the first time, $31.4 \%(n=11)$ were undergoing the second treatment and $34.3 \%(n=12)$ had been treated three or more times. There was a statistically significant difference between the median times of problematic use of substances between the Justice System Group (Med $=7.00$ years, Min $=0$ year, $Q_{1}=3.00, Q_{3}=10.00, M a x=22$ years, $=7.9$ years, $S D=5.73$ years) and the Others Group ( $\mathrm{Med}=10$ years, $M i n=1$ year, $Q_{1}=5.00, Q_{3}=16.50, \operatorname{Max}=40$ years, $=12.00$ years, $\mathrm{SD}=8.94$ years), with differences between the groups (Mann-Whitney $U=1074.50, p=.021$ ).

\section{Discussion}

The study presented interesting results regarding the motivation of those referred by the criminal justice system, considering the initial hypothesis. According to the URICA Scale for Illicit Substances, it was shown that the motivation of people referred by the criminal justice system did not differ from the people referred for treatment by other sources, such as by the family or by themselves. However, differences were observed between the groups regarding the location in the stage of motivation for change of behavior. In addition, the results of the total sample are similar to those obtained in the validation study of the URICA Scale for Illicit Substances (Szupszynski \& Oliveira, 2008).

The division between groups aimed to better analyze the possible differences between the two groups with different referrals for treatment, with no statistical differences found between the groups regarding the motivation variables. However, the study by Prendergast, Greenwell, Farabee, and Hser (2009) demonstrated that prisoners undergoing treatment obtained low means in the
Socrates Scale sub-scales of "recognition" and "ambivalence" and high means in decision-making for the resolution of the problem with drugs. Therefore, this equality of the groups stands out, since Action and Maintenance are seen as stages in which the negation of the problem and the ambivalence about changing behavior have dissipated (Prochaska, 2013). On the other hand, the results of a study, in which the URICA scale was also applied, showed that after the application of the Short Motivational Program (SMP), a protocol to increase motivation, the offenders did not move between the stages, with regressions to previous stages, which generated doubts about the application of the stages of change with this population (Yong, Williams, Provan, Clarke, \& Sinclair, 2015).

The data from the Readiness Ruler requires attention since, being an analogical-visual instrument, it demonstrates, in an objective way, the opinion of the participant and how much he/she is prepared to effect the change, this being subjective and rich motivational data. In the analysis of the Readiness Ruler between the groups, there was also no statistically significant difference in the median values $(p=.083)$. A study, with 395 crack users, showed similar measures for the Readiness Ruler, in which the high correlation between high scores in this instrument with the Action stage was already theorized, with results in the time of abstinence (Szupszynski, Sartes, Andretta, \& Oliveira, 2014).

Regarding the number of participants in the Justice System Group ( $n=35)$, this amount corresponded to almost all the individuals referred by VEPEMA in the second half of 2015 and the first half of 2016. Accordingly, it should be noted that this small number was due to the fact that the Therapeutic Justice project started in 2014 and was in its pilot phase, therefore, there were no large scale referrals. There were also three cases in which the referrals were not located, all in the outpatient model that were considered as losses and, in addition, five refusals to participate in the study were counted: three from the Justice System Group and two from the Others Group. Two of the people, among the three in the Justice Group, who refused to participate, reported 
that this would cause problems with the judge and that they would only talk about the referral with people of the justice system; the third person was unwilling to participate. The other two people who refused to participate, of the Others Group, only stated that they did not want to participate in the study. The rate of losses or refusals, corresponding to $6.6 \%$, was not expected to compromise the intended comparative analysis, drawing attention to some people's fear of talking about their motivation.

It should be noted that the referral by the justice system occurred voluntarily and, sometimes, at the request of the people themselves. The VEPEMA Therapeutic Justice project is based on the expectation of changing the individual's behavior and on the new public policies for treatment. This reflects the intensification and concern about the modification of drug use behavior in the prison population in recent years. Although the majority of people referred chose to be treated in TCs, a study commissioned by the National Secretariat for Drug Policy (SENAD) and carried out by the Instituto de Pesquisa Econômica Aplicada (IPEA) showed that the referral by the justice system is small: only $9 \%$, with the family accounting for the highest rates of referral for treatment in TCs (IPEA, 2016).

The sample profile is of individuals with multiple drug use, most of them male and with evident social and occupational impairments. Studies concerning the group of people with problems with the criminal justice system corroborate these data, where the low level of education, due to being economically low classes, and the high unemployment rate create difficulties in the social reinsertion of people with legal problems (Oliveira \& Cardoso, 2004; Tavares, Scheffer, \& Almeida, 2012). Only $24.2 \%$ of the individuals were classified in the D-E classes, therefore, it can be considered that individuals of the least favored social class only accounted for a small proportion of those that participated in this study, however with low levels of education and high unemployment.

Comparing the number of women treated $(n=17,14.2 \%)$ with the men $(n=103,85.8 \%)$, it can be hypothesized that this phenomenon is also a reflection of what happens in the majority of the country: a small provision of treatment directed toward those of the female sex, due to being technically unprepared for this type of population (Rennó Jr et al., 2005). Only four women were referred for treatment by the court after being imprisoned for drug trafficking. The study by Lopes, de Mello, and Argimon (2010) portrayed the problem of crimes and drug use in women prisoners, in which the majority of the sample had a direct relationship with drugs, whether regarding use or sale. Although studies indicate the increase in consumption and also the number of drug-related arrests, such as trafficking (Laranjeira et al., 2012; Ministério da Justiça, 2015), this type of benefit, the referral, has not yet been widely extended to women.

As presented in Table 4, no differences between the treatment models were found in the Justice System Group. This statistical equality demands attention, as there is a debate about the effectiveness of the treatment models, however, in the context of this study, the CTs were more sought after than the CAPS-AD by the participants of the Therapeutic Justice project. The therapeutic resources offered in each treatment model may be linked to this greater demand and even influence the motivation. The subjects can expect a quick solution to their problem from the hospitalization, therefore they are briefly involved in the treatment, where labor therapy, spiritual and religious work, cooperation and being far from the stressful stimuli or those that elicit the craving contribute to the greater demand. The treatment in democratic TCs is recommended to increase motivation since the referral can lead to treatment without motivation and, once the cognitive and behavioral techniques have been applied, it can have therapeutic success (Stevens, 2013).

Regarding the number of days of abstinence in the comparison between the treatment models, it is clear that in the outpatient model (CAPS$\mathrm{AD}$ ), where abstinence is not required, the subjects commonly maintain the use of alcohol and other drugs even in treatment situations, which can influence the stage of motivation. Cropsey et al. (2014) argued that among one of the tasks 
to work on and increase rates of motivation, directed towards abstinence, is working with the expectations of individuals within judicial treatment programs. In this sense, the expectations of those referred may be linked to the desire to have their legal record cleared.

Data on the problems associated with use are highlighted, since in the total sample, $74.2 \%$ used drugs daily and $56.7 \%$ had already committed some small crime to maintain their drug use, especially concerning crack. However, the study by Guimarães, Santos, Freitas, and Araújo (2008) indicated that there was no association between the pattern of crack use and severity of dependence when analyzing the criminal history of crack users who were undergoing detoxification in a psychiatric hospital. The study by Tavares et al. (2012) found a strong correlation between drug use, criminal recidivism and type of crime (robberies) with aggressiveness, in which the most commonly used drug was alcohol. In the present study, the participants in the Justice System Group reported that the most prevalent crimes were drug trafficking $(42.9 \%)$ and robbery $(25.7 \%)$.

Also regarding the data about crack use, even though it is not the substance most consumed in life by the participants, it was responsible for the majority of the cases of seeking treatment $(50.8 \%)$, which included 16 people from the Justice System Group $(n=35)$. The study of Sousa, Ribeiro, Melo, Maciel, and Oliveira (2013) evaluated, using the URICA Scale, the stages of change in crack and alcohol user patients hospitalized in a Therapeutic Community and in a hospital, demonstrating that the people undergoing treatment for the use of crack were more motivated than the alcohol users and that the people hospitalized in the TC were also more motivated than those in the hospital.

In all, 10 participants from the Justice System Group reported that they did not consider getting treatment for themselves before knowing that they could take advantage of this benefit, where they also informally told the researchers that they thought they were obliged to do so. The Justice Therapy project does not oblige individuals to enter and continue treatment, that is, it does not coerce them, unlike treatment programs in the United States. Regarding coercion, it should be noted that cases of this kind of intervention strategy may still be effective, however, research shows that lasting changes occur when the subjects are truly motivated to change their behavior (Farabee, Prendergast, \& Anglin, 1998). Furthermore, a systematic review of studies on compulsory treatment did not find evidence that this model as a whole shows better results, with some studies suggesting possible harm, such as human rights abuses (Werb et al., 2016).

From the data obtained, the high use of sedatives in the treatment was highlighted: $98 \%$ of the sample of 55 individuals made use of these through medical indication, which were regularly prescribed for Anxiety Disorders and sleeping problems at the beginning of the treatment, when the Withdrawal Syndrome occurs. A study of prison inmates found a high prevalence of psychiatric comorbidities and personality disorder associated with the Substance Use Disorder (Bennett \& Hunter, 2016). Although the aims of this study did not cover the use of these drugs, it is advised that the use of sedatives for long periods tends to produce dependence.

Although the participants were not in prison, some techniques can be studied and put into practice in the context of out-of-prison treatment for Therapeutic Justice, such as the BSF (Beteende-Samtal-Förändring) protocol, translated as Behavior-Conversation-Change. This is based on the Motivational Interview in conjunction with five semi-structured sessions focused on substance use and criminal behavior (Farbring $\&$ Johnson, 2011). The prisoners were evaluated through the SOCRATES scale and, after the intervention, the changes were more significant in ambivalence and action, thus demonstrating that the steps to improve public policies with drug users should follow tested models that value motivation and can sustain a more lasting change.

These results provide important information for researchers, as well as for other actors involved in the Therapeutic Justice project, such 
as the judiciary, treatment institutions, those convicted and their family members. Motivation is an important component in changing problematic behavior and evaluating it becomes fundamental in referral programs such as the Therapeutic Justice project. In recent years, Brazil has had several debates about drug use and its effects on society and on crime rates, where the awareness of increasingly offering treatment in certain situations involving drugs, as in the case of people with problems with the criminal justice system, and motivation is of paramount importance for the success of these programs.

Therapeutic Justice constitutes an alternative measure that values health, with this cohesion with the justice system directed not toward coercion and punishment. The project proposes that, between punishment in a closed regime and treatment, the second option is the best. Individuals are able to solve their problem with the use of drugs and still fulfill their sentence, away from the prison environment and the risks that it constitutes. Judicial programs of referral for treatment for drug use are not new. Since the 1990s, international studies related to the criminal justice system have already indicated some practices that should be implemented in these programs, such as longer treatment periods, post-treatment follow-up, good facility structure, program flexibility (non-authoritarian) and provision of medical care and job training (Anglin \& Hser, 1991). Therefore, challenges to be overcome, such as the lack of preparation of partner institutions, such as the TCs, can be explained by the conditions in which some operate, often without qualified human resources or with a lack of financial resources.

This study has some limitations, such as the high disparity between the Justice System Group and the Others Group, which made a more consistent statistical comparison impossible. However, this is a study with a sample that will tend to increase as the results of the program start to emerge. Another limitation was the fact that the study project did not evaluate the stage of motivation in referred adolescents. Although in the state there is already a proposal for the referral of adolescents to treatment, there is still the difficulty of adherence to treatment and lack of structure for care, with the Therapeutic Justice project being aimed at those over 18 years of age.

It is hoped that with the continuation of the project, there will be more training of the teams of the judiciary and those of the institutions, seeking to work more on the psychological and motivational aspects, performing the evaluation of the motivational stage to overcome possible resistance to treatment. Furthermore, an increase in the number of people referred according to the genders is recommended, including more individuals without conditions to have their rights guaranteed by lawyers. With the increasing demand for treatment, it is suggested to invest in the continuity of studies that cover the stages of motivation with this population in Brazil, including larger samples and better conditions of representativeness, which, on this occasion, due to the still small number of subjects referred, could not be performed. Finally, it is necessary to carry out follow-up studies with this referred population, in order to verify the results of this important public policy in the long term.

\section{Authors' Contributions}

Substantial contribution in the concept and design of the study: Itamar José Félix Junior e Paulo Renato Vitória Calheiros.

Contribution to data collection: Itamar José Félix Junior.

Contribution to data analysis and interpretation: Itamar José Félix Junior, Paulo Renato Vitória Calheiros e Pedro di Tárique Barreto Crispim.

Contribution to manuscript preparation: Itamar José Félix Junior, Paulo Renato Vitória Calheiros e Pedro di Tárique Barreto Crispim.

Contribution to critical revision, adding intelectual content: Itamar José Félix Junior, Paulo Renato Vitória Calheiros e Pedro di Tárique Barreto Crispim.

\section{Conflicts of interest}

The authors declare that they have no conflict of interest related to the publication of this manuscript. 


\section{References}

Associação Brasileira de Empresas de Pesquisa. (2015). Critério de classificação econômica Brasil 2015. Retrieved from http://www.abep. org/criterioBrasil.aspx

Anglin, M. D., \& Hser, Y. I. (1991). Criminal justice and the drug-abusing offender: Policy issues of coerced treatment. Behavioral Sciences \& The Law, 9(3), 243-267. doi: 10.1002/ bsl.2370090304

Bertolucci, P. H., Brucki, S., Campacci, S. R., \& Juliano, Y. (1994). O mini-exame do estado mental em uma populaçäo geral: Impacto da escolaridade. Arquivos de NeuroPsiquiatria, 52(1), 1-7. doi: 10.1590/S0004282X1994000100001

Bennett, A., \& Hunter, M. (2016). Implementing evidence-based psychological substance misuse interventions in a high secure prison based personality disorder treatment service. Advances in Dual Diagnosis, 9(2-3), 108-116. doi: 10.1108/ ADD-02-2016-0002

Cropsey, K. L., Leventhal, A. M., Stevens, E. N., Trent, L. R., Clark, C. B., Lahti, A. C., \& Hendricks, P. S. (2014). Expectancies for the effectiveness of different tobacco interventions account for racial and gender differences in motivation to quit and abstinence self-efficacy. Nicotine \& Tobacco Research, 16(9), 1174-1182. doi: $10.1093 / \mathrm{ntr} / \mathrm{ntu} 048$

El-Bassel, N., Schilling, R. F., Ivanoff, A., Chen, D. R., Hanson, M., \& Bidassie, B. (1998). Stages of change profiles among incarcerated drug-using women. Addictive Behaviors, 23(3), 389-394

Farbring, C. A., \& Johnson, W. R. (2011). Entrevista Motivacional no Sistema Prisional - Uma tentativa de implementar a Entrevista Motivacional na Justiça Criminal. In $\mathrm{H}$. Arkowitz, H. A. Westra, W. R. Miller, \& S. Rollnick, Entrevista Motivacional no tratamento de problemas psicológicos (pp. 253-267). São Paulo, SP: Roca.

Farabee, D., Prendergast, M., \& Anglin, M. D. (1998). The Effectiveness of Coerced Treatment for Drug-Abusing Offenders. Federal Probation, 62(1), 3-10. Retrieved from http://heinonline. org $/ \mathrm{HOL} /$ LandingPage?handle=hein.journals/ fedpro62\&div $=5 \& \mathrm{id}=\&$ page $=$
Guimarães, C. F., Santos, D. D., Freitas, R. D., \& Araújo, R. B. (2008). Perfil do usuário de crack e fatores relacionados à criminalidade em unidade de internação para desintoxicação no Hospital Psiquiátrico São Pedro de Porto Alegre (RS). Revista de Psiquiatria do Rio Grande do Sul, 30(2), 101-108. doi: 10.1590/S010181082008000300005

Instituto de Pesquisa Econômica Aplicada. (2016). Nota Técnica Perfil das Comunidades Terapêuticas Brasileiras. Retrieved from http://www. ipea.gov.br/portal/index.php?option=com_cont ent\&view $=$ article $\&$ id $=29865 \&$ Itemid $=6$

Kelly, J. F., Finney, J. W., \& Moos, R. (2005). Substance use disorder patients who are mandated to treatment: Characteristics, treatment process, and 1-and 5-year outcomes. Journal of Substance Abuse Treatment, 28(3), 213-223. doi: 10.1016/j.jsat.2004.10.014

Laranjeira, R., Madruga, C. S., Ribeiro, M., Pinsky, I., Caetano, R., \& Mitsuhiro, S. S. (2012). II LENAD-Levantamento Nacional de Álcool e Drogas. São Paulo, SP: Instituto Nacional de Ciência e Tecnologia para Políticas Públicas do Álcool e Outras Drogas.

Law No. 11,343. (2006, August 24). Institui o Sistema Nacional de Políticas Públicas sobre Drogas Sisnad; prescreve medidas para prevenção do uso indevido, atenção e reinserção social de usuários e dependentes de drogas; estabelece normas para repressão à produção não autorizada e ao tráfico ilícito de drogas; define crimes e dá outras providências. Diário Oficial da União. Retrieved from http://www.planalto.gov.br/ ccivil_03/_ato2004-2006/2006/lei/11 1343.htm

Lopes, R. M., de Mello, D. C., \& Argimon, I. I. (2010). Mulheres encarceradas e fatores associados a drogas e crimes. Ciências \& Cognição, 15(2), 121-131. Retrieved from http://pepsic.bvsalud. org/scielo.php?script=sci_arttext\&pid=S180658 $212010000200011 \& \operatorname{lng}=$ pt\&tlng $=$ pt

Ministério da Justiça. (2015). Levantamento Nacional de Informações Penitenciárias-Infopen Mulheres 2014. Retrieved from https://www. justica.gov.br/noticias/estudo-traca-perfil-dapopulacao-penitenciaria feminina-no-brasil/ relatorio-infopen-mulheres.pdf

Oliveira, H. B. D., \& Cardoso, J. C. (2004). Tuberculose no sistema prisional de Campinas, São 
Paulo, Brasil. Revista Panamericana de Salud Pública, 15(3), 185-193. doi: 10.1590/S102049892004000300008

Oliveira, M. D. S., Ludwig, M. W. B., Freire, S., \& Zanetello, L. B. (2012). O modelo transteórico de mudança no enfoque grupal. In I. Andretta \& M. D. S. Oliveira (Eds.), Manual Prático de Terapia Cognitivo-Comportamental (pp. 455466). São Paulo, SP: Casa do Psicólogo.

Oliveira, M. D. S., Szupszynski, K. P. D. R., \& DiClemente, C. (2010). Estudo dos estágios motivacionais no tratamento de adolescentes usuários de substâncias psicoativas ilícitas. Psico, 41(1). Retrieved from http://revistaseletronicas.pucrs.br/ojs/index.php/revistapsico/article/ view/7207/0

Polaschek, D. L., Anstiss, B., \& Wilson, M. (2010). The assessment of offending-related stage of change in offenders: Psychometric validation of the URICA with male prisoners. Psychology, Crime \& Law, 16(4), 305-325. doi: $10.1080 / 10683160802698766$

Prendergast, M., Greenwell, L., Farabee, D., \& Hser, Y. I. (2009). Influence of perceived coercion and motivation on treatment completion and rearrest among substance-abusing offenders. The Journal of Behavioral Health Services \& Research, 36(2), 159-176. doi: 10.1007/s11414008-9117-3

Prochaska, J. O. (2013). Transtheoretical model of behavior change. In Encyclopedia of behavioral medicine (pp. 1997-2000). New York: Springer.

Prochaska, J. O., DiClemente, C. C., \& Norcross, J. C. (1992). In search of how people change: Applications to addictive behaviors. American Psychologist, 47, 1102-1114. doi: 10.1037/0003066X.47.9.1102

Rennó, J., Jr., Fernandes, C. E., Mantese, J. C., Valadares, G. C., Fonseca, Â. M., Diegoli, M., ...Hochgraf, P. (2005). Saúde mental da mulher no Brasil: Desafios clínicos e perspectivas em pesquisa. Revista Brasileira de Psiquiatria, 27(Supl. 2), S73-S76. Retrieved from http://www.scielo.br/pdf/rbp/v27s2/pt a07v27s2.pdf

Serafini, K., Stewart, D. G., Wendt, D. C., \& Donovan, D. M. (2017). Perceived parental support and adolescent motivation for substance use change: A preliminary investiga- tion. Addiction Research \& Theory, 1-6. doi: 10.1080/16066359.2017.1342819

Soares, M. M., Filho, \& Bueno, P. M. M. G. (2016). Demografia, vulnerabilidades e direito à saúde da população prisional brasileira. Ciência \& Saúde Coletiva, 21(7), 1999-2010. doi: 10.1590/141381232015217.24102015

Sousa, P. F., Ribeiro, L. C. M., Melo, J. R. F. D., Maciel, S. C., \& Oliveira, M. X. (2013). Dependentes químicos em tratamento: Um estudo sobre a motivação para mudança. Temas em Psicologia, 21(1), 259-268. doi: 10.9788/ TP2013.1-18

Stevens, A. (2013). Prisoners' motivations for therapeutic community treatment In search of a 'different'approach to offender rehabilitation. Probation journal, 60(2), 152-167. doi: $10.1177 / 0264550513478321$

Szupszynski, K. P. D. R., \& Oliveira, M. D. S. (2008). Adaptação brasileira da University of Rhode Island Change Assessment (URICA) para usuários de substâncias ilícitas. PsicoUSF, 13(1), 31-39. Retrieved from http://pepsic. bvsalud.org/scielo.php?script=sci_arttext\&pid= S141382712008000100005\&lng=pt\&tlng=pt

Szupszynski, K. P. D. R., Sartes, L. M. A., Andretta, I., \& Oliveira, M. D. S. (2014). Processos de mudança cognitivos e comportamentais em usuários de crack em tratamento. Revista Brasileira de Terapias Cognitivas, 10(1), 11-18. doi: https:// dx.doi.org/10.5935/1808-5687.20140003

Tavares, G. P., Scheffer, M., \& Almeida, R. M. M. D. (2012). Drogas, violência e aspectos emocionais em apenados. Psicologia: Reflexão e Crítica, 25(1), 89-95. Retrieved from http://www. scielo.br/pdf/prc/v25n1/a11v25n1

Velasquez, M., Maurer, G., Crouch, C., \& DiClemente, C. (2001). Group treatment for substance abuse: A stages-of- change therapy manual. New York: The Guilford Press.

Werb, D., Kamarulzaman, A., Meacham, M. C., Rafful, C., Fischer, B., Strathdee, S. A., \& Wood, E. (2016). The effectiveness of compulsory drug treatment: A systematic review. International Journal of Drug Policy, 28, 1-9. doi: 10.1016/j. drugpo.2015.12.005

Wilson, D. B., Mitchell, O., \& MacKenzie, D. L. (2006). A systematic review of drug court ef- 
fects on recidivism. Journal of Experimental Criminology, 2(4), 459-487. doi: 10.1007/ s11292-006-9019-4

Yong, A. D., Williams, M. W. M., Provan, H., Clarke, D., \& Sinclair, G. (2015). How do offenders move through the stages of change?
Psychology, Crime \& Law, 21(4), 375-397. doi: 10.1080/1068316X.2014.989166

Received: $22 / 06 / 2017$

$1^{a}$ revision: $17 / 08 / 2017$

Accepted: 22/08/2017 distribution, and reproduction in any medium, provided you give appropriate credit to the original author(s) and the source, provide a link to the Creative Commons license, and indicate if changes were made. 